\title{
IMPLEMENTASI HUDUD DALAM PANDANGAN ULAMA FIQIH; STUDI KRITIS TEHADAP KITAB FIQIH ‘ALA MAZAHIB AL ARBA’AH.
}

Oleh:

\author{
Mibahul Khairani
}

STIS Samarinda, Indonesia

Susanto

IAIN Samarinda, Indonesia

STIS SAMARINDA, Indonesia

ibn_aqil@yahoo.com

\begin{abstract}
Abstrak
Kajian ini dengan pembahasan "Implementasi Hudud Dalam Pandangan Ulama Fiqih; Studi Kritis Kitab Fiqih 'Ala Mazahib al Arba'ah". Penelitian ini menggunakan library risearch (Studi Pustaka) dengan menggunkan pendekatan deskriptif kualitatif. Penelitian ini mendiskripsikan pandangang para ulama tentang hudud dan mengkajinya; hudud merupakan sanksi (hukuman) yang kadarnya telah ditentukan oleh Allah SWT, tidak ada hak bagi hakim untuk mrngurangi atau menambahnya. Ada beberapa hal yang termasud dalam jinayah hudud diantaranya adalah Zina dan minum khamar. Zina terbagi menjadi dua yaitu zina muhshan hadanya adalah rajam dan ghairu muhshan hadnya adalah jild dan taghrib. Penetapan had zina bisa dilakukan dengan dua cara yaitu: syahadah (persaksian) sebanyak empat orang dan Iqrar (pengakuan) pelaku. Perbutaan yang menyerupai zina seperti, menyewa perempuan untuk berzina sanksinya di kenakanan had zina, melakukan zina dengan mahram sanksinya dalah dibunuh, melakukan perbutan homoseksual sanksinya adalah had, lesbian dan melakukan perzinahan selain zina farji sanksinya adalah ta'zir, melakukan onani dan melakukan zina terhadap binatang sanksinya dalah ta'zir. Khamar bagi peminumnya dikenai had yaitu di dera sebanyak 80 kali, hukumnan ini diputuskan berdasarkan saksi (terdiri dua orang laki-laki) dan pengakuan
\end{abstract}

Kata Kunci: implementasi, Hudud, Ulama Fiqih 
Mibahul Khairani, Susanto: Implementasi Hudud dalam Pandangan Ulama Fiqih; Studi Kritis Tehadap Kitab Fiqih 'Ala Mazahib Al Arba'ah

\section{A. Pendahuluan}

Allah SWT mencipakan manusia di dunia adalah sebagai khalifah Allah dimuka bumi dan tugasnya untuk memakmurkan dan memanfaatkan bumi dengan baik bukan hal sebaliknya yaitu merusaknya, oleh karena itu Allah SWT membekalinya dengan akal agar mereka bisa memikirkan sesuatau yang dilhat dan dirakasan, dan membekalinya dengan nafsu agar mampu berdinamika dan berkarya. Selain itu Allah turunkan syari'at untuk menjaga hak-hak manusia dan menjaga kehidupan mereka dari kezhaliman dan kerusakan. Fungsi syari'at ini juga untuk menjaga dan memelihara agama, jiwa, keturunan, akal dan harta. Sehingga setiap orang yang melanggar salah satu masalah ini harus mendapatkan hukuman yang ditetapkan syari'at dan disesuaikan dengan pelanggaran tersebut. Salah satunya adalah penegakan hudud.

Syari'at merupakan salah satu jalan untuk menjaga kehormatan manusia dan mengatur kehidupan yang lebih baik dan mapan. Oleh karenamya syari'at yang diturunkan tidaklah membebani atau bahkan merugikan umat manusia, melainkan diturunkan sesuai dengan apa yang dibutuhkan, namun manusia yang terkadang menganggap syari'at yang diturunkan kepadanya membawa mudharat.

Hudud adalah rahmat untuk makhluk dan kebaikan bagi mereka. Oleh karena itu, sudah sepatutnya orang yang menghukum manusia karena dosa-dosa mereka, bertujuan melakukannya untuk kebaikan dan rahmat kepada mereka, sebagaimana tujuan orang tua membina anak-anaknya dan dokter dalam mengobati orang yang sakit.

Syari'at Islam ditegakkan berdasarkan asas keadilan tidak tebang pilih ataupun pilih kasih, siapa yang melakukan jarimah maka akan mendapatkan sanksi baik itu kaya atau miskin, muda atau tua, dari kalangan konglomerat ataupun kalangan biasa, seperti yang termaktub dalam Hadits Nabi SAW:

"Dari Aisyah ra. berkata: bahwa kaum Quraisy sangat dipusingkan dengan seorang perempuan suku Makhzum yang melakukan pencurian. Mereka mengatakan, "Siapa yang bisa berbicara dengan Rasulullah Saw (yaitu mengemukakan permintaan supaya perempuan itu 
Mibahul Khairani, Susanto: Implementasi Hudud dalam Pandangan Ulama Fiqih; Studi Kritis Tehadap Kitab Fiqih 'Ala Mazahib Al Arba'ah

dibebaskan)?" Tidak ada yang mau berbicara tentang hal itu, kecuali Usamah kesayangan Rasulullah Saw. Rasulullah Saw mengatakan, "Apakah engkau hendak menolong supaya orang bebas dari hukuman Allah SWT?" Kemudian Nabi SAW berdiri lalu berkhutbah, "Hai sekalian manusia, orang-orang sebelum kamu menjadi sesat hanyalah disebabkan apabila seorang bangsawan mencuri, mereka biarkan (tidak melaksanakan hukuman kepadanya) dan bila orang miskin mencuri, mereka tegakkan had padanya. Demi Allah SWT, kalaulah seandainya Fatimah binti Muhammad mencuri, niscaya Muhammad memotong tangannya."

Dari riwayat diatas menujukkan adilnya syari'at ini meneggakkan sanksi bagi siapapun tanpan harus memandang siapa pelakunya, dan bahkan dilarang untuk memberikan rekomendasi pembebasan kepada orang yang dianggap terhormat.

Setelah penjelasan di atas penulis merasa tertarik untuk menkaji masalah ini, karena di zaman modern ini syari'at hudud ini mulai ditinggalkan oleh umat Islam, bahkan banyak yang belum mengetahui tentang adanya hukum hudud dalam Islam, sehingga sebagian besar umat Islam phobia ketika mendengar istilah tersebut dan bahkan menganggap hal itu bertentangan dengan hak asasi manusia (HAM), oleh karenanya penulis berusaha mengkaji dan menyuguhkan kembali syari'at yang hampir dilupakan ini. Dalam kajian ini penulis akan mengakat syari'at hudud dan mengkajinya dengan menelusuri kitab-kitab fikih klasik ataupun modern dan kitab tafsir, untuk menyingkap syari'at hudud ini, bagaimana disyari'atkannya, pelaksaannya dan sanksinya, merujuk pada pendapat-pendapat ulama yang termaktub dalam kitab-kitab tersebut.

\section{B. Landasan Teori}

Makna Hudud adalah kosa kata dalam bahasa Arab yang merupakan bentuk jama' (plural) dari kata had yang asal artinya pembatas antara dua benda. Dinamakan had karena mencegah bersatunya sesuatu dengan yang

${ }^{1}$ Abu Abdullah Muhammad bin Ismail Al Bukhari, Shahin Al Bukhari, Jilid VI, (Kairo: Maktabah Nazar Musthafa al Baz, 2004), h. 1477.

Al Qalam: Jurnal Ilmiah Keagamaan dan Kemasyarakatan Vol. 13, No. 2, Juli-Desember 2019 
Mibahul Khairani, Susanto: Implementasi Hudud dalam Pandangan Ulama Fiqih; Studi Kritis Tehadap Kitab Fiqih 'Ala Mazahib Al Arba'ah

lainnya. Ada juga yang menyatakan bahwa kata had berarti al-man'u (pencegah), sehingga dikatakan Hudud adalah perkara-perkara yang Allah SWT larang melakukan atau melanggarnya. ${ }^{2}$

Hudud dalam istilah syar'i, istilah adalah hukuman-hukuman kemaksiatan (kejahatan) yang telah ditetapkan oleh syara' untuk mencegah terjerumusnya seseorang kepada kejahatan yang sama. ${ }^{3}$ Kata hudud terkadang dipakaikan untuk maksiat itu sendiri (maksiat yang diperbuatnya). ${ }^{4}$ hudud juga diartikan dengan hal yang Allah haramkan untuk dilakukan, ${ }^{5}$ seperti yang termaktub dalam Al-Qur'an :

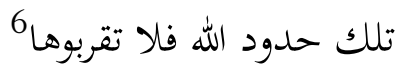

Artinya: "Itu adalah hudud Allah maka jangan kamu mendekatinya".

Hudud menurut ulama Hanafi adalah hukuman yang kadarnya sudah ditentukan dengan pasti oleh Allah SWT. ${ }^{7}$ Sedangkan menurut para fuqaha hudud adalah sanksi-sanksi yang telah di tentukan kadarnya sesuai syari'at yang telah di tetapkan oleh Allah SWT. ${ }^{8}$

Dari beberepa istilah hudud yang di kemukakan oleh ulama-ulama diatas, tidaklah jauh berbeda. Hudud adalah sanksi-sanksi (hukuman) bagi individu ataupun kelompok yang melakukan perbuatan maksiat (melanggar ketentuan Allah SWT yang mana perbuatan tersebut sudah ditentukan oleh Allah SWT melalui syairi'atnya (Al-Qur'an dan Hadits) kadar sanksinya, tidak

\footnotetext{
2Majma' Lughah Arabiyah, Al Mu'jam Al Wajiz, (Kairo: Wijzarah At Tarbiyah Wa At Ta'lim, 2006), h. 139.

${ }^{3}$ Muhammad Zuhaili, Al Mu'tamad Fi Fiqhi As Syafi'i, Juz. V, (Damaskus: Dar Al Qalam, 2011), h. 145.

${ }^{4}$ Muhammad Al Jazairy, Fiqh 'Ala Mazahib Al Arba'ah, Jil. 5, (Damaskus: Darul Qutub Ilmiyah), h. 12 tt), h.12.

${ }^{5}$ Wahbah Zuhaily, Fiqih Islam Wa Adillatuhu, Jil. VI, (Damskus:Dar Al Fikri,

${ }^{6}$ Q.S Al Baqarah Ayat: 187

${ }^{7}$ Wahbah Zuhaily, Fiqih Islam..., h.12.

${ }^{8}$ Muhammad Zuhaili, Al Mu'tamad..., h. 155.
} 
Mibahul Khairani, Susanto: Implementasi Hudud dalam Pandangan Ulama Fiqih; Studi Kritis Tehadap Kitab Fiqih 'Ala Mazahib Al Arba'ah

boleh dikurangi ataupun dilebihkan dan tidak ada unsur belas kasihan terhadap pelakunya.

\section{Metode Penelitian}

Jenis penelitian yang digunakan peneliti adalah penelitian kepustakaan (library reseach) data diambil dari kepustakaan baik berupa buku, dokumen maupun artikel. ${ }^{9}$ Atau suatu penelitian dengan cara membaca atau meneliti menggunakan buku-buku yang ada kaitannya dengan permasalahan judul dalam penelitian. Penelitian ini juga menggunakan pendekatan kualitatif deskriptif analisis kritis, penggunaan pendekatan deskriptif kualitatif dalam penelitian ini karena data yang dikumpulkan berdasarkan kata-kata tertulis. ${ }^{10}$

Analisis data yang digunakan sesuai jenis data dan sifat data yang diperoleh dari penelitian ini, penulis juga menggunakan analisis isi (content analysis) larena tekni ini digunakan untuk mempelajari dokumen. Lexy J. Meleong mengatakan bahwa teknik yang paling umum digunakan untuk menganalisis dokumen adalah content analysis atau dinamakan kajian isi. Content analysis digunakan oleh peneliti dalam rangka untuk menarik kesimpulan garis besar dari beberapa kitab fiqih klasik. Adapun langkahlangkah dalam content analysis terdiri dari beberapa kegiatan yaitu: 1) Data diorganisir seefektif mungkin sehingga peneliti mudah untuk memperoleh kualitas data yang baik, mendokumentasikan analis yang dilakukan, dan menyimpan data serta analisis yang berkaitan dengan penyelesaian penelitian. Data diorganisir berdasarkan tema pokok dalam penelitian. 2) Melakukan analisis data untuk menemukan tema dan mendiskripsikannya. 3) Pengujian terhadap hasil analisis data dilakukan dengan membandingkan tema dan sub tema dengan mempelajari kembali smber data yang ada. 4) Interpretasi data yang sudah dimiliki.

9 Sugiono, Metode Penelitian Kuantitatif, Kualitatif dan $R \& D$, cet. 19 (Bandung: Alfabet, 2013), h.95

${ }^{10}$ Lexy J. Meleong, Metododlogi Penelitian Kualitatif (Bandung: PT. Remaja RosdaKarya, 2003), h.3.

Al Qalam: Jurnal Ilmiah Keagamaan dan Kemasyarakatan Vol. 13, No. 2, Juli-Desember 2019 
Mibahul Khairani, Susanto: Implementasi Hudud dalam Pandangan Ulama Fiqih; Studi Kritis Tehadap Kitab Fiqih 'Ala Mazahib Al Arba'ah

\section{Hasil Penelitian}

\section{Hudud Dalam Pandangan Ulama Islam}

Syari'at hudud terdapat di dalam Al-Qur'an, seperti ayat tentang sariqah, ayat tentang zina, ayat tentang qazaf, ayat tentang muharibah. Di dalam Sunah Nabawy juga terdapat hadits yang berbicara tentang had, diantaranya hadits $M a{ }^{\prime} i z$ dan hadits Juhainah. ${ }^{11}$

Hudud menurut ulama-ulama fikih adalah hukuman/sanksi yang kadarnya sudah ditentunkan oleh Allah, kapanpun seorang hakim mengetahui seseorang melakukan kejahatan yang harus di jatuhi had, maka wajib melaksakan had atasnya, dan seorang hakim tidak memiliki wewenang untuk membebaskannya, karena had adalah hak Allah SWT. ${ }^{12}$

\section{Macam-Macam Perbuatan yang Dikenai Hukum Hudud}

Jarimah al-Hudud yang meliputi kasus hudud meliputi tujuh jenis: 1) Had zina (hukuman zina) ditegakkan untuk menjaga keturunan dan nasab. 2) Had al-Qadzf (hukuman orang yang menuduh berzina tanpa bukti) untuk menjaga kehormatan dan harga diri. 3) Had al-Khamr (hukuman orang minum khamar (minuman memabukkan) untuk menjaga akal. 4) Had as-Sariqah (hukuman pencuri) untuk menjaga harta. 5) Had al-Hirabah (hukuman para perampok) untuk menjaga jiwa, harta dan harga diri kehormatan. 6) Had alBaghi (hukuman pembangkang) untuk menjaga agama dan jiwa. 7) Had arRiddah (hukuman orang murtad) untuk menjaga agama.

Dari kasus jarimah hudud diatas penulis tidak membahas secara keseluruhan, namun hanya membahas sebagiannya saja. Dikarenakan banyaknya pembahasan hudud tersebut, jadi penulis hanya membatasi pembahasan tentang had zina dan had Syarbu al khmar dikarenakan luasnya masalah ini dan banyak terkait dengan kehidupan modern saat ini.

\footnotetext{
${ }^{11}$ Lihat Muhammad al Jazairy, Fiqih Ala Mazahib....,h.11

${ }^{12}$ Lihat Muhammad al Jazairy, Fiqih Ala Mazahib....,h.12
} 
Mibahul Khairani, Susanto: Implementasi Hudud dalam Pandangan Ulama Fiqih; Studi

Kritis Tehadap Kitab Fiqih 'Ala Mazahib Al Arba'ah

\section{Macam-Macam Hudud dan Hukuman (Sanksi) Bagi Pelakunya \\ a. Zina dan ketentuan hukumnya}

\section{1) Pengertian dan hukum zina}

Kata zina mengandung arti tanah larangan, sedangkan menurut istilah bahwa zina adalah perbuatan bersenggama antara laki-laki dan perempuan yang tidak terikat oleh hubungan pernikahan. Sedangkan ulama fiqih memberi batasan pengertian zina sebagai berikut:

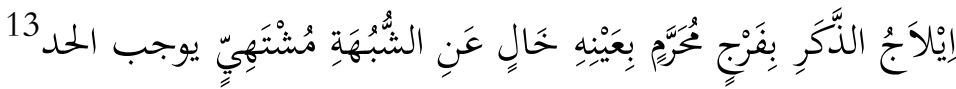

"Memasukan alat kelamin laki-laki ke dalam alat kelamin perempuan (dalam persetubuhan) yang haram menurut perbuatannya bukan karena subhat dan perempuan itu mendatangkan syahwat."

Adapula yang mengartikan zina dengan bercampurnya antara laki-laki dengan wanita tanpa melalui akad yang sesuai dengan syar'i. Dari berbagai pengertian tersebut yang jelas zina adalah suatu perbuatan yang sangat tercela dan pelakunya pantas mendapatkan hukuman yang sangat berat.

Sebagaimana yang diketahui bahwa perbuatan zina dalam bentuk apapun hukumnya haram. Masyarakat berpandangan bahwa perbuatan zina mengarah pada hubungan di luar nikah saja. Namun sesungguhnya makna zina itu hakikatnya luas, sebagaimana hadits yang diriwayatkan oleh Abi Hurairah r.a. Rasul SAW perna bersabda:

"Sesungguhnya Allah telah menetapkan nasib anak Adam mengenai zina, tidak mustahil pernah melakukannya. Zina

\footnotetext{
${ }^{13}$ Abu Zakaria Mahyuddin Yahya bin Syaraf, Ali bin Abdul Kafi As Subki, Al Majmu Syarh Al Muhadzab, Jilid 22 (Kairo: Mathba'ah Al Ashimah, tt), h. 22.
} 
Mibahul Khairani, Susanto: Implementasi Hudud dalam Pandangan Ulama Fiqih; Studi Kritis Tehadap Kitab Fiqih 'Ala Mazahib Al Arba'ah

mata ialah melihat, zina lidah ialah berkata, zina hati ialah keinginan dan syahwat, sedangkan faraj (kemaluan) adalah hanya menuruti atau tidak menuruti". ${ }^{14}$

Zina faraj (kemaluan) merupakan puncak dari perbuatan keji bagi mereka yang tidak biasa menjaga diri dari perbuatan, ucapan, pikiran dan penglihatan yang dilarang agama. Karena itulah penting bagi seorang mukmin menjaga diri dan anggota tubuhnya terperangkap dengan perbuatan yang mengarah pada zina. Untuk itulah Allah SWT berfirman:

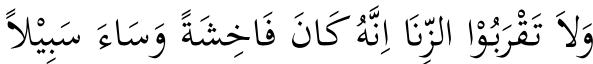

Artinya: "Dan janganlah kamu mendekati zina, sesungguhnya zina itu adalah suatu perbuatan yang keji dan suatu jalan yang buruk." (QS. Al-Isra, 32)

Suatu hari Rasulullah ditanya oleh Abdullah Bin Mas'ud ra.:

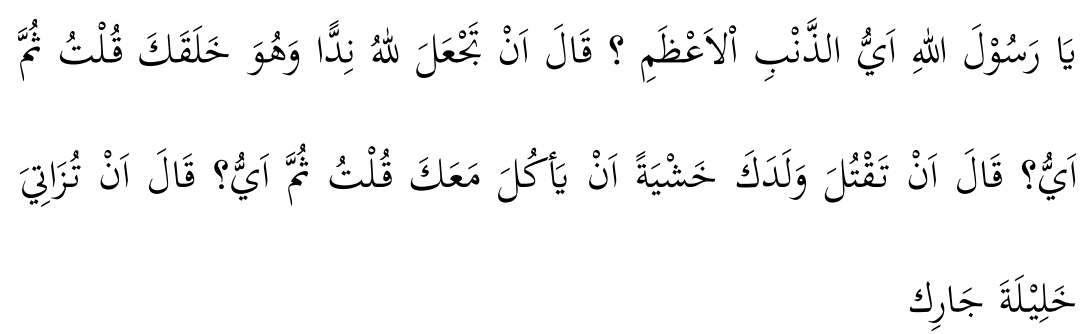

Artinya: "Ya Rasulallah dosa apa yang paling besar dalam pandangan Allah? Jabaw beliau: "engkau menjadikan tandingan Allah, padahal dia yang menciptakanmu”. Terus apalagi? tanyaku, jawabnya, "engkau memmbunuh anakmu, Karena takut miskin”. Lalu siapa lagi? Tanyaku, Beliau menjawab lagi:

${ }^{14}$ Lihat shahih muslim

Al Qalam: Jurnal Ilmiah Keagamaan dan Kemasyarakatan Vol. 13, No. 2, Juli-Desember 2019 
Mibahul Khairani, Susanto: Implementasi Hudud dalam Pandangan Ulama Fiqih; Studi Kritis Tehadap Kitab Fiqih 'Ala Mazahib Al Arba'ah

“engkau berzina dengan isteri tetanggamu.” (HR. Bukhari dan Muslim)

\section{2) Penetapan hudud bagi pelaku zina (fahisyah)}

Syari'at menjamin kehormatan seseorang, karena syari'at ini ditegakkan untuk siapapun dan dimanapun tanpa memilah dan memilih, untuk menentukan had pelaku zina, ditetapkan oleh hakim, melalui dua cara, yaitu Syahadah (persaksian) dan pengakuan dari orang yang berzina $(\text { Ikrar })^{15}$

Pertama; memutuskan had zina dengan persaksian, saksi tersebut terdiri dari empat orang, laki-laki, mukallaf (baligh dan berakal sehat), adil (bukan fasiq), merdeka (bukan budak), Islam dan memberikan keterangan kesaksian yang sama tentang tempat, waktu, pelaku dan cara melakukannya. ${ }^{16}$ Jadi jika tidak lengkap salah satu syarat-syarat di atas, maka belum bisa ditetapkan zina, sampai adanya bukti yang akurat. Adapun disebutkan dalam firman Allah SWT:

Artinya: "Dan (terhadap) para wanita yang mengerjakan perbuatan keji, hendaklah ada empat saksi di antara kamu (yang menyaksikan). Kemudian jika mereka memberi persaksian, maka kurunglah mereka (wanita-wanita itu) dalam rumah sampai mereka menemui ajalnya atau sampai Allah memberi jalan kepadanya”. (QS. Al-Nisa,4;15).

Memutuskan had zina salah satunya melalui syahadah (persaksian), saksi yang harus didatangkan ditengah-tengah pesidangan atau di depan hakim sebanyak empat orang, jika kurang dari empat orang maka batal persaksian tersebut dan tuduhan zina terhadap pelaku dianggap mengada-ada.

\footnotetext{
${ }^{15}$ Muhammad Zuhaili, Al Mu'tamad Fi Fiqhi As Syafi'i, Juz. V, (Damaskus: Dar Al Qalam, 2011), h. 163.

${ }^{16}$ Wahbah Zuhaily, Fiqih Islam Wa Adillatuhu, Jilid. VI, (Damaskus:Dar Al Fikri, tt), h.47-48.
} 
Mibahul Khairani, Susanto: Implementasi Hudud dalam Pandangan Ulama Fiqih; Studi Kritis Tehadap Kitab Fiqih 'Ala Mazahib Al Arba'ah

Seperti yang disebutkan dalam kitab fiqh ala mazahib ala arba'ah

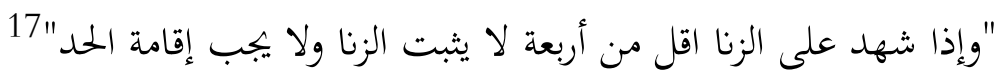

Artinya: "Apabila yang menjadi saksi atas perbuatan zina kurang dari empat orang, maka tidak dibenarkan tuduhan zina tersebut dan tidak wajib dilaksanakan had".

Adapun tentang hukuman bagi saksi (kurang dari empat orang) yang bersaksi terhadap perbutan zina tersebut ada beberapa komentar ulama, diantaranya ada yang mengatakan tidak dikenakan sanksi, jika dikenakan sanksi akan membuat orang enggan untuk bersaksi dalam kasus jarimah (kejahatan), dikarenakan tidak terjamin keamanannya dan keselamatan bagi saksi. ${ }^{18}$ Namun ada juga kalangan ulama yang mewajibkan sanksi bagi saksi, karena dia telah menuduh dan tidak bisa mendatangkan empat orang saksi. ${ }^{19}$ Masalah ini pernah terjadi di zaman Umar bin Khatab, ada tuduhan perbuatan zina yang mendatangkan empat orang saksi, setelah melakukan penyelidikan terhadap empat saksi tersebut, dan salah satu saksi tidak dapat menjelaskan kronologi kejadian dengan benar. Seperti dia hanya mengatakan: "bahwa fulan dengan

${ }^{17}$ Abdurrahman Al Jazairy, Kitab al Fiqhi 'Ala Madzahib al Arba'ah, Juz V, (Beirut: Dar Al Fikri Al Ilmiyah, 1990), h. 76.

${ }^{18}$ Lihat Abdurrahman Al Jazairy, Kitab al Fiqhi.., h. 76.

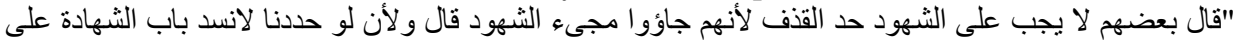

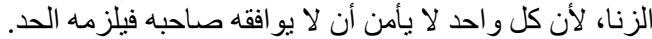

Artinya: "Sebagian ulama berpendapat tidaklah wajib bagi saksi (kurang dari empat orang) had qazaf, mereka datang sebagai saksi (pent. Bukang menfitnah) dan jika saksi dikenakan had maka akan tertutup pintu persaksian tersebut, karena setiap orang yang bersaksi tidak terjamin keamannya jika tidak sesuai dengan pelakunya".

${ }^{19}$ Lihat Abdurrahman Al Jazairy, Kitab al Fiqhi..., h. 76.

"الحنفية قالو ا يجب حد القذف على الثهود، إذا كان أقل من أربعة، لأن الثاهد الواحد لما شهده فقد قذفه ولم يأت بأربعة من الثهاء فوالبراء فوجب عليه الحد.

Artinya: "Ulama-ulama dari kalangan madzhab hanafi berkomentar: wajib dikenakan had qazaf atas saksi yang kurang dari empat orang, karena satu orang yang bersaksi (terhadap kasus perzinahan) dan tidak bisa mendatangkan empat orang saksi maka dia sudah menfitnahnya".

Al Qalam: Jurnal Ilmiah Keagamaan dan Kemasyarakatan Vol. 13, No. 2, Juli-Desember 2019 
Mibahul Khairani, Susanto: Implementasi Hudud dalam Pandangan Ulama Fiqih; Studi Kritis Tehadap Kitab Fiqih 'Ala Mazahib Al Arba'ah

fulanah sedang berkemul satu selimut", Umar bin Khatab mendera mereka tanpa bertanya apakah ada saksi yang lain. ${ }^{20}$

Penetapan zina berdasarkan saksi dapat disahkan jika saksi terdiri dari empat orang laki-laki (terpenuhi syarat-syaratnya), melihat kejadian tersebut dengan detail, jelas, tanpa ragu-ragu/mengada-ada dan dapat menjelaskan kronologi terjadinya perzinahan tersebut. Jika tidak terpenuhi empat orang saksi, maka dikenakan had qazaf bagi saksi, hal ini dimaksud agar manusia tidak mudah bersaksi untuk hal-hal yang besar yang mengakibatkan sanksi bagi orang lain. Selain itu had qazaf ini adalah salah satu cara agama Islam menjaga kehormatan seseorang dari fitnah dan tuduhan yang membahayakan bagi pelaku (dirajam).

Penentuan had zina tidaklah mudah, dengan hanya mendatangkan empat orang saksi kemudian jatuhlan sanksi bagi pelaku, namun perlu melewati beberapa tahapan, dari mulai terpenuhi syarat-syarat saksi, penjelasan saksi, kemudian baru diputuskan oleh hakim. Had zina adalah merupan perkara besar karena itu perlunya kehati-hatian dalam memutuskan masalah ini, ketika saksi kurang dari empat orang atau empat orang namun salah satu tidak bisa menjelaskan kronologi dengan benar maka berhak had qazaf bagi saksi. Hal ini dilakukan oleh syari'at Islam dalam mengambil mudharat yang terkecil yaitu dera (Jild) bukan rajam. ${ }^{21}$ Dalam syari'at Islam perbuatan zina akan dikenai had meskipun hanya disaksikan oleh satu orang laki-laki saja dengan cara li'an, jika yang dituduh berbuat zina adalah istrinya. ${ }^{22}$

\footnotetext{
${ }^{20}$ Lihat Abdurrahman Al Jazairy, Kitab al Fiqhi..., h. 76.

${ }^{21}$ Lihat http//www. Jaafaridris.com, diakses 13 Nopember 2017. Ada kaidah yang berbunyi "ارتكاب أخف الضرورين" artinya: Jika terjadi dua masalah yang "درء المفاسد مقدم على جلب الصالح" memberikan mudhrat maka diambil yang paling ringan artinya: Menutup pintu kerusakan lebih utama daripada mengambil manfaat.

${ }^{22} \mathrm{Li}$ 'an adalah perkataan suami seperti "saya persaksikan kepada Allah bahwa saya benar terhadapa tuduhan saya kepada istri saya bahwa dia telah berzina" perkataan tersebut diulangi empat kali, kemudian ditambahnya dengan kalimat, "laknat Allah akan menimpaku sekiranya aku dusta dalam tuduhanku ini"., lihat Sulaiman Rasjid, Fiqih Islam, (Bandung: Sinar Baru Algesindo offset, 2013), h. 412-413.
} 
Mibahul Khairani, Susanto: Implementasi Hudud dalam Pandangan Ulama Fiqih; Studi Kritis Tehadap Kitab Fiqih 'Ala Mazahib Al Arba'ah

Kedua; Pengakuan pelaku (ikrar) menurut ulama Hanafiyah bahwasannya yang berikrar tersebut adalah orang yang sudah baligh dan berakal sebanyak empat kali mengakui perbuatan zina di depan qadhi (hakim). ${ }^{23}$ Tujuan pengakuan ini, disamping untuk mencocokan, juga sebagai bukti kuat (otentik) ditetapkannya hukum hudud, baik lisan maupun tulisan pelaku.

Dari Abi Hurairah ra. berkata: "Ada seorang laki-laki mendatangi Rasulullah SAW, lalu berkata, 'Ya Rasulallah, Saya telah berzina. Namun, beliau berpaling, sampai ia mengulanginya empat kali. Setelah itu ia bersaksi atas dirinya sebanyak empat kali, maka Nabi SAW memanggilnya dan bertanya' "Apakah kamu gila? Jawab laki-laki itu, 'Tidak.' Apakah kamu sudah menikah? Jawabnya lagi, 'Ya' kalau begitu pergilah kamu dengannya, lalu ranjamlah ia!”. (HR. Al-Bukhariy). ${ }^{24}$

Qarinah (indikasi), bukti pelaku baik dari laki-laki maupun perempuan. Yang paling meyakinkan adalah adanya kehamilan, meskipun masih dalam kandungannya. Hal ini pernah dikatakan oleh Umar Bin Khaththab r.a., "Bahwa saksi zina wajib dikenakan atas setiap pelaku zina, jika ada pembuktian hamil atau pengakuan.

Qarinah ini khusus untuk wanita yang belum menikah (bukan sebab akibat perkosaan), akan tetapi era saat ini di mana tes DNA atau sejenisnya bisa dijadikan salah satu alternatif dalam mendukung indikasi perzinahan.

\section{3) Macam-macam zina dan hukumannya}

Zina dalam kajian fiqih Islam terbagi ke dalam dua bagian, yaitu: Pertama; Zina orang yang sudah menikah (zina Muhshan) adalah zina yang dilakukan oleh orang yang masih atau pernah ada tali ikatan

\footnotetext{
${ }^{23}$ Wahbah Zuhaily, Fiqih Islam..., h.48.

${ }^{24} \mathrm{Abu}$ Abdullah Muhammad bin Ismail Al Bukhari, Shahin Al Bukhari, Jilid VI, (Kairo: Maktabah Nazar Musthafa al Baz, 2004), h.
} 
Mibahul Khairani, Susanto: Implementasi Hudud dalam Pandangan Ulama Fiqih; Studi Kritis Tehadap Kitab Fiqih 'Ala Mazahib Al Arba'ah

perkawinan. Dengan kata lain, masih punya suami atau isteri atau sudah janda atau duda. ${ }^{25}$

Pelakunya baik laki-laki maupun wanita yang melakukan zina muhshan maka diranjam ${ }^{26}$ atau dilempari batu tanpa belas kasihan sampai meninggal dunia. ${ }^{27}$ Dalam sebuah hadits diceritakan,

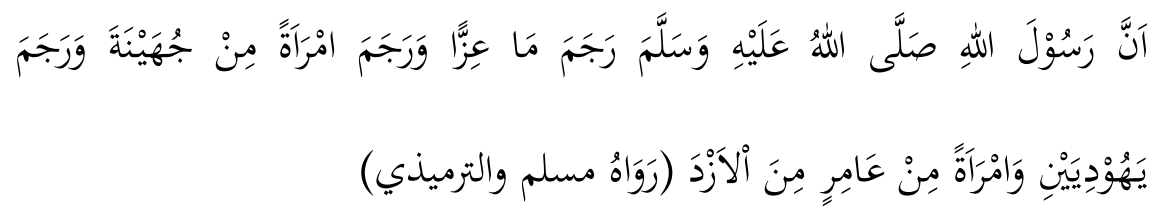

Artinya: "Sesungguhnya Rasulullah merajam seorang yang bernama Maiz dan meranjam seseorang perempuan yang berasal dari bani Juhainah, dan dua orang yahudi dan seorang perempuan dari kabilah Amir dari suku Azd". (HR. Muslim dan AlTurmidzi).

Kedua; Zina orang yang belum menikah (zina ghairu muhshan) adalah pelaku yang belum pernah menikah. ${ }^{28}$ Hadnya adalah 100 kali dicambuk dan diasingkang selama satu tahun. ${ }^{29}$ Hal ini sesuai dengan firman Allah SWT:

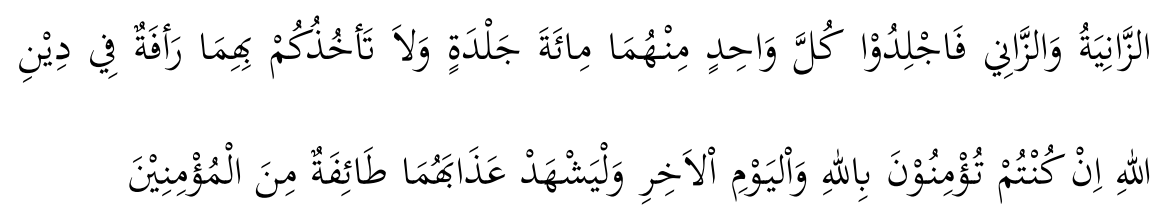

Artinya: "Perempuan dan laki-laki yang berzina, maka deralah tiap-tiap seorang dari mereka 100 kali deraan, dan janganlah kalian belas kasihan kepada keduanya mencegah kau menjalankan agama Allah, jika kamu beriman kepada Allah dan hari kiamat,

\footnotetext{
${ }^{25}$ Lihat Sulaiman Rasjid, Fiqih Islam..., h. 436.

${ }^{26}$ Rajam adalah melempari penzina dengan batu (sebesar gemgaman tangan). Lihat Muhammad Zuhaili, Al Mu'tamad..., h. 157

${ }^{27}$ Muhammad Zuhaili, Al Mu'tamad..., h. 155.

${ }^{28}$ Lihat Sulaiman Rasjid, Fiqih Islam..., h. 436.

${ }^{29}$ Muhammad Zuhaili, Al Mu'tamad..., h. 158
} 
Mibahul Khairani, Susanto: Implementasi Hudud dalam Pandangan Ulama Fiqih; Studi Kritis Tehadap Kitab Fiqih 'Ala Mazahib Al Arba'ah

dan hendaklah (pelaksanaan hukuman mereka disaksikan oleh sekumpulan orang-orang yang beriman", 30

Sabda Nabi Muhammad SAW:

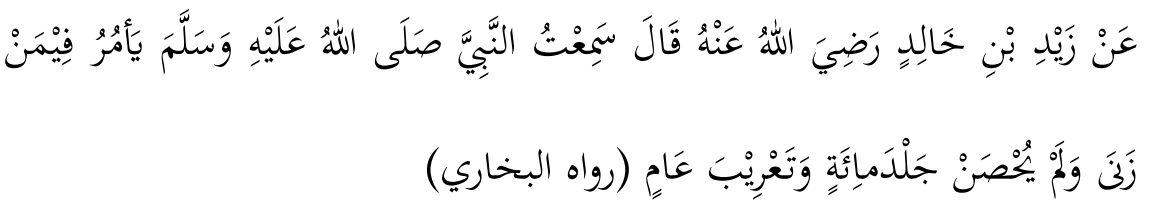

Artinya: "Dari Zaid Bin Khalid r.a., berkata, "Aku pernah mendengar Nabi SAW memerintahkan mencambuk pezina yang belum menikah dengan 100 kali deraan dan dibuang selama satu tahun".

Perbutan zina yang dilakukan oleh orang yang belum menikah, maka sanksi baginya adalah di dera sebanyak seratus kali dan di asingkan dari kampung halamnya selama satu tahun.

\section{4) Tata cara Rajam, Jild, dan Taghrib}

Melaksankan rajam bagi laki-laki atau perempuan yang berzina yang sudah menikah (Muhshan), jika yang berzina seorang laki-laki dilaksankan dengan berdiri, tanpa diikat tangan atau kakinya, tidak dipegangi, tidak di masukan ke lubang dan ditimbun dengan tanah sampai ke dada, menutup auratnya, baik dijatuhkan had dengan bukti (saksi) atau dengan ikrar (pengakuan). ${ }^{31}$

Perempuan (muhshan) yang berzina yang dijatuhkan putusan hukumannya dengan bayyinah (saksi), tubuhnya ditimbun dalam galian tanah sampai dadanya agar tidak tersingkap auratnya. Dan jika dijatuhi hukumnya dengan ikrar (pengakuan), tidak di timbun di dalam tanah agar memungkinkan dia untuk lari dan mencabut pengakuannya. ${ }^{32}$

\footnotetext{
${ }^{30} \mathrm{Al}$ Qur'an Surah An Nur ayat:2

${ }^{31}$ Wahbah Zuhaily, Fiqih Islam..,h. 60.

${ }^{32}$ Muhammad Zuhaily, Al Mu'tamad..., 157.
} 
Mibahul Khairani, Susanto: Implementasi Hudud dalam Pandangan Ulama Fiqih; Studi Kritis Tehadap Kitab Fiqih 'Ala Mazahib Al Arba'ah

Keputusan had (sanksi) zina muhshan (sudah pernah menikah) dengan ikrar (pengakuan), jika dia lari dan menghindar disaat dirajam maka jangan dikejar kemungkinan dia akan menarik ucapan pengakuannya (ikrar), akan tetapi jika keputusan berdasarkan saksi dan melarikan diri saat dirajam maka wajib di kejar. ${ }^{33}$

Pelaksanaan Jild (cambuk/dera) menggunakan tongkat (tidak terlalu besar/kecil), bukan dengan tongkat yang masih baru dan keras, bukan yang keras dan basah, mendera semua anggota tubuh, agar semua anggota tubuh mendapatkan hak merasakan sakitnya dibagian tubuh yang mendapatkan kenikmatan, dan menghindari muka dan kemaluanya, seperti yang pernah dilakukan Ali ra. Melaksanakan had, dan mengatakan kepada tukang dera: "pukullah!! Dan berikan setiap tubuh haknya, hindarilah wajah dan kemaluannya". 34

Pelaksanaan Taghrib (pengasingan) terhadap zina ghairu muhshan dengan cara mengasingkan dari daerahnya ke daerah yang lain dengan jarak terdekat tidak bisa mendengar kabar dengan cepat selama satu tahun tidak di penjara, kalau dia kembali sebelum masa satu tahun maka wajib diasingkan kembali. Jika yang diasingkan adalah perempuan harus bersama suaminya atau mahramnya karena wanita tidak diperkenankan bepergian seorang diri. ${ }^{35}$

\footnotetext{
${ }^{33}$ Pernah terjadi di zaman Rasulullah SAW, seseorang yang bernama Ma'iz datang kepada Rasulullah mengakui perbuatan zinanya, kemudian Rasulullah menyuruh membawanya untuk dirajam, ketika dirajam Maiz sempat menghindar dari tempat yang batunya sedikit ke suatu tempat yang batunya lebih banyak, dan di ikuti (kejar) oleh para sahabat Nabi SAW dan merajamnya sampai meninggal, kemudian diadukan perkara tersebut kepada Rasulullah Saw, Beliau SAW mejawab, Maha Suci Allah, kenapa tidak engkau biarkan dia berlari dari depanmu. Lihat Muhammad Zuhaily, Al Mu'tamad..., 158.

${ }^{34}$ Muhammad Zuhaily, Al Mu'tamad..., 160.

${ }^{35}$ Rasulullah bersabda yang diriwayatkan dari Abu Hurairah: 'Tidak halal bagi perempuan yang beriman kepada Allah dan hari akhir untuk mushafir jarak tempuh sehari semalam yang tidak ditemani oleh mahramnya". Lihat Shahih Bukhari jilid I h. 369.
} 
Mibahul Khairani, Susanto: Implementasi Hudud dalam Pandangan Ulama Fiqih; Studi

Kritis Tehadap Kitab Fiqih 'Ala Mazahib Al Arba'ah

\section{5) Hal-hal yang Terkait Had Zina}

(a) Liwath (homo seksual)

Liwath adalah mendatangi (memasukkan) melalui dubur, baik itu dubur laki-laki ataupun perempuan. Hal ini merupakan perbuatan keji dan termasuk dosa besar yang diharamkan oleh Allah. Sesuai dengan firman Allah:

$$
\text { ولوطا إذ قال لقومه أتأتون الفاحشة ما سبقكم بها من أحد من العالمين }
$$

Artinya: "Dan Kami mengutus Luth, ingatlah ketika dia berkata kepada kaumnya; apakah kalian akan melakukan perbuatan keji yang belum pernah dilakukan oleh salah seorang di antara kalian yang belum pernah dilakukan didunia ini'”.(QS. Al-A'raf:80)

Allah mengazab perbuatan mereka, ketika mereka melakukannya di zaman Nabi Luth yang tidak mengindahkan nasehat dan tegurannya.

Sanksi bagi pelaku homo seksual menurut pendapat Imam Malik, Imam Syafi'i dan Imam Ahmad, wajib dijatuhkan had bagi pelaku homo seksual, karena Allah SWT sangat keras menghukum pelaku liwath seperti yang termaktub dalam Al-Qur'an. ${ }^{36}$ Sedangkan menurut Abu Hanifah, pelaku liwath di ta'zir jika tidak ada percampuran nasab dalam liwath, dan tidak ada muncul perkara yang bersinggungan yang mengarah pada dibunuhnya pelaku liwath. ${ }^{37}$

Had liwath menurut pendapat Malikiyah dan Hanabilah yang azhar adalah di rajam, bagaimanapun keadaannya, baik yang sudah menikah maupun belum menikah, seperti yang termaktub dalam hadits Rasulullah SAW: "Barangsiapa yang menemukan perbuatan kaumnya Nabi Luth, maka bunuhlah kedua pelakunya", dalam lafaz

\footnotetext{
${ }^{36}$ Wahbah Zuhaily, Fiqih Islam..,h. 66.

${ }^{37}$ Wahbah Zuhaily, Fiqih Islam..,h. 66.
} 
Mibahul Khairani, Susanto: Implementasi Hudud dalam Pandangan Ulama Fiqih; Studi Kritis Tehadap Kitab Fiqih 'Ala Mazahib Al Arba'ah

yang lain "Rajamlah yang di atas dan yang di bawah". ${ }^{38}$ Adapun menurut Syafiiyah pelaku liwath dikenakan had rajam bagi mereka yang sudah menikah dan dikenakan had jild bagi yang belum menikah. ${ }^{39}$

Suami yang mendatangi istrinya lewat belakang (jimak lewat dubur) hukumnya haram karena diangggap syubhah (samar), perbuatan ini tidak dijatuhi had tetapi ta'zir. ${ }^{40}$

Dari beberapa pendapat ulama di atas dapat disimpulkan bahwasanya sanksi dari perbuatan homo seksual adalah had rajam/dibunuh, karena perbuatan ini dianggap sebagai perbuatan keji dan menyalahi fitrah sebagai manusia.

(b) Sihaq (Lesbi)

Sihaq adalah perempuan yang mendatangi perempuan (untuk melampiaskan nafsu). Perbuatan ini merupakan perbuatan dosa yang diharamkan oleh Allah dan sanksi bagi pelakunya adalah ta'zir bukan had, karena perbuatan ini seperti perbuatan laki-laki yang mencumbu rayu perempuan tanpa memasukkan zakar ke dalam farj'. Hal ini termasuk perbuatan yang diharamkan oleh Allah seperti yang termaktub dalam hadits Nabi yang diriwayatkan oleh Abu Musa AlAsy’ari ra.

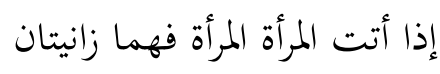

Artinya: "Apabila seorang perempuan mendatangi (untuk melampiaskan birahi) perempuan maka mereka berdua termasuk orang yang berzina. ${ }^{41}$

Dengan demikian dapat dikatakan bahwa pelaku lesbi disamakan dengan perbuatan laki-laki ataupun perempuan yang

${ }^{38}$ Wahbah Zuhaily, Fiqih Islam..,h.37.

${ }^{39}$ Wahbah Zuhaily, Fiqih Islam..,h.37.

${ }^{40}$ Raudhah at Thalibin...,jilid.10, h.91

${ }^{41}$ Muhammad Zuhaili, Al Mu'tama..., h. 167. 
Mibahul Khairani, Susanto: Implementasi Hudud dalam Pandangan Ulama Fiqih; Studi Kritis Tehadap Kitab Fiqih 'Ala Mazahib Al Arba'ah

melakukan hubungan syahwat bukan zina hakiki dikenakan sanksi ta'zir.

(c) Isti'jarul Al Mar'ah li Azzina

Isti 'jarul Al Mar'ah li Azzina adalah laki-laki yang menyewa perempuan untuk melakukan zina dan perempuan tersebut bersedia untuk melakukan zina. Menurut kalangan ulama Hanafi perbuatan ini tidak dijatuhi had tetapi keduanya di ta'zir dan mereka berdua akan mendapatkan bagian dosa zina dihari kiamat. ${ }^{42}$ Sedangkan menurut kalangan ulama Maliki, Syafi'i dan Hanbali perbuatan ini dikenakan had bagi keduanya. ${ }^{43}$

Dari penelusuran pendapat dari kalangan ulama-ulama tentang wanita yang di sewa, maka dikenakan hukum had bagi mereka. Hal ini hampir tidak ada perbedaan dikalangan ulama.

(d) Zina bil Maharim

Zina bil Maharim adalah melakukan perbuatan zina dengan mahram (orang yang dilarang untuk dinikahi), baik mahram itu karena mushaharah (hubungan nikah) semisal mertua, atau karena hubungan nasab, dan atau karena radha'ah (sepersusuan). Dalam kasus ini ada beberapa pendapat ulama, diantaranya pendapat Jabir bin Abdullah ra.: “dipenggal lehernya, hartanya diberikan ke baitul mal sebagai sanksi atas perbuatannya dan sebagai pelajaran bagi orang lain karena perbuatan ini merupakan virus berbahaya dalam kasus jinayah. ${ }^{44}$

\footnotetext{
${ }^{42}$ Diriwayatkan bahwa ada seorang perempuan yang meminta susu dari seorang pengembala kambing dipadang pasir tapi pengembala tersebut enggan memberikan susu tersebut kecuali perempuan tersebut mau menyerahkan tubuhnya, perempuan ini setelah berfikir panjang karena dia sangat memerlukan minuman tersebut akhirnya perempuan ini menerima tawaran pengembala kambing tersebut, lalu kemeudian pengembala tersebut menyetubuhinya. Kemedian perkara ini di adukan kepada Umar bin Khatab ra. beliau tidak menjatuhkan had kepada keduanya dan berkata ini adalah maharnya (susu) yang telah dijanjikan untuknya. Lihat Kitab Fiqh Ala Mazahib Arba'ah..., h.88.

${ }^{43}$ Kitab Fiqh Ala Mazahib Arba'ah..., h. 89

${ }^{44}$ Muhammad al jazairy, fiqh ala mazahub..., h.90
} 
Mibahul Khairani, Susanto: Implementasi Hudud dalam Pandangan Ulama Fiqih; Studi Kritis Tehadap Kitab Fiqih 'Ala Mazahib Al Arba'ah

Imam Ahmad dan Ishaq berkomentar: "wajib dibunuh pelakunya baik dia bujangan atau sudah menikah, terlebih khusus kalau perempuan tersebut mantan istri bapaknya (ibu tiri). Seperti sebuah riwayat dari Al Bara', dia berkata: saya bertemu dengan pamanku dan bersamanya rayah (bendera), aku berkata padanya: kamu mau kemana? Dia menjawab: Rasulullah telah mengutusku kepada seseorang yang telah menikahi istri bapaknya agar aku memenggal kepalanya dan mengambil hartanya. (HR. Abu Daud) ${ }^{45}$

Setelah menelusuri beberapa pendapat para ulama, riyawat yang datang dari para sahabat dapat ditarik kesimpulan bahwa zina yang dilakukan terhadap mahramnya merupakan perbuatan yang amat keji bahkan pelakunya dianggap lebih rendah dari binatang. Ulama sepakat tentang sanksi yang dijatuhkan pada pelakunya yaitu di bunuh karena hal ini menyalahi fitrah sebagai manusia dan merusak jalur nasab dan keturunan.

(e) Al Istimna'

Al Istimna' adalah perbuatan yang dilakukan seorang laki-laki untuk mengeluarkan sperma atau disebut dengan onani. ${ }^{46}$ Hal ini termasuk perbuatan yang diharamkan oleh Allah SWT, seperti dalam firman Allah:
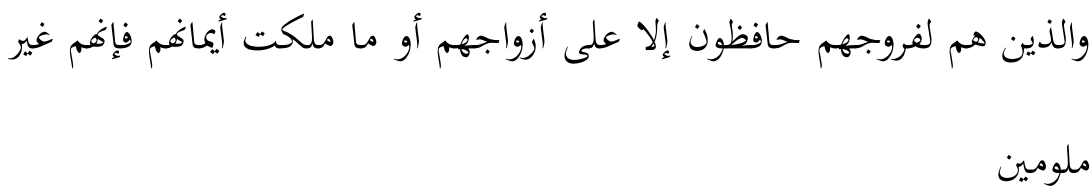

Artinya: "Mereka adalah orang-orang yang menjaga kemaluannya, kecuali terhadap istri-istri dan budak sahaya mereka”.

Perbuatan ini diharamkan seperti halnya liwath karena memutus keturunan dengan perbuatan keji tersebut. Istimna' ini tidak

\footnotetext{
${ }^{45}$ Muhammad al jazairy, fiqh ala mazahub..., h.90

${ }^{46}$ Muhammad Zuhaili, Al Mu'tamad.., h. 168.
} 
Mibahul Khairani, Susanto: Implementasi Hudud dalam Pandangan Ulama Fiqih; Studi Kritis Tehadap Kitab Fiqih 'Ala Mazahib Al Arba'ah

dijatuhi had seperti liwath karena perbuatan ini tidak memasukan zakar kedalam farj ataupun dubur.

(f) Wat'u Al Mayyitah

Di antara perbuatan keji yang dilakukan manusia adalah menyetubuhi mayat, dalam hal ini ulama berbeda pendapat tentang sanksi yang dijatuhkan pada pelaku mujrim tersebut; menurut para ulama yang bernaung dalam mazhab Maliki berpendapat bahwa dikenakan had bagi mereka yang menyetubuhi mayat karena hal itu semisal farj anak Adam yang hidup bahkan hal ini termasuk perbuatan dosa besar dikarena perbuatan tidak pantas dilakukan kepada mayat. Sedangkan menurut para Ulama yang bernaung dalam mazhab Hanafi, Syafi'i, dan Hanbali adalah orang yang menyetubuhi mayat tidak dikenakan Had namun di ta'zir dan ta'dib, pendapat ini merupakan pendapat rajih dari kalangan ulama ini. ${ }^{47}$

Dari penelusuran dari beberapa pendapat ulama tentang kasus diatas bisa ditarik kesimpulan bahwa perbuatan tersebut dikenai had karena perbuatan tersebut termasuk perbuatan menyalahi tabiat manusia, yang mana manusia itu tidak ingin berkumpul dengan mayat apalagi untuk melakukan perbutan keji tersebut.

(g) Ityan Al Bahimah

Perbuatan keji terhadap binatang yang di lakuakan oleh manusia diantaranya adalah menyetubuhi binatang, dalam kasus ini para ulama fikih dikalangan empat mazhab sepakat bahwa pelaku perbuatan keji ini tidak di kenakan had tapi dikenakan sanksi ta'zir yang diputuskan oleh hakim. ${ }^{48}$ Hal seperti yang di

${ }^{47}$ Wahbah Zuhaili, Fiqh Islami.., h. 67-68. Lihat Imam Nawawi, Majmu...,h. 65.

${ }^{48}$ Wahbah Zuhaili, Fiqh Islami.., h. 67. Lihat Muhammad Zuhaili, Al Mu'tamad..., h.169. 
Mibahul Khairani, Susanto: Implementasi Hudud dalam Pandangan Ulama Fiqih; Studi Kritis Tehadap Kitab Fiqih 'Ala Mazahib Al Arba'ah

sebutkan oleh Ibnu Abbas Ra. "tidaklah orang yang mendatangi binatang (menyetubuhi) atasnya had"49

Orang yang sehat pikirannya tidak akan melakukan perbuatan keji (menyetubuhi) binatang, hal itu lahir karena kurang sehatnya akal pelaku perbuatan tersebut. Perbuatan ini termasuk perbuatan dosa yang diharamkan oleh Allah.

(h) Al Mar'atu Al Mukrahah

Al Mar'atu Al Mukrahah atau disebut dengan perempuan yang dipaksa berzina/diperkosa, seperti halnya ketika perempuan sedang tidur kemudian digauli oleh laki-laki, maka perempuan ini tidak dijatuhi had, ${ }^{50}$ akan tetapi wajib di jatuhkan had atas orang yang memaksanya.

\section{b. Minuman yang Memabukkan (khamar)}

\section{1) Pengertian minuman yang memabukkan dan dasar hukum dilarangnya minuman keras}

Dalam kajian fiqih Islami tema pembasan ini adalah khamr dan yang memabukkan, ulama Hanafi memandang tentang hal yang memabukkan ini ada dua macam had nya, yaitu: 1) had memabukkan (muskir) dan 2) had minuman (Syurbun). Had syurbi (minuman) hanya berlaku untuk minuman yang bernama khamar, sedikit ataupun banyak, memabukkan ataupun tidak maka harus kenakan sanksi had. Seperti sabda Rasulullah SAW: "Barangsiapa yang meminum khamar maka cambuklah..,". 51 Adapun had memabukkan adalah apapun jenis minumuan yang memabukkan meskipun selain khamar maka dikenakan sanksi had. ${ }^{52}$ Sedangkan menurut jumhur ulama tidak membedakan

\footnotetext{
${ }^{49}$ Imam Syaukani, Nailul Authar.., h. 308.

${ }^{50}$ Diriwayatkan dari Wail bin Hajar bahwasannya seorang perempuan dipaksa (zaman Rasulullah) maka Rasulullah Saw membebaskan dia dari had dan Rasulullah menjatuhkan vonis had untuk laki-laki tersebut., lihat Sunan Tirmizi....

${ }^{51}$ Imam Syaukani, Nailul Authar, Jilid 7 (Beirut), h. 167

${ }^{52}$ Wahbah Zuhaily, Fiqih Islam..,h. 148-149.
} 
Mibahul Khairani, Susanto: Implementasi Hudud dalam Pandangan Ulama Fiqih; Studi Kritis Tehadap Kitab Fiqih 'Ala Mazahib Al Arba'ah

antara had syurbun dengan had sakr (memabukkan), karena anggapan jumhur setiap yang memabukkan adalah khamar, sedikit ataupun banyak hukumnya haram. ${ }^{53}$

Pengertian khamar dari segi bahasa artinya penutup akal. Sedangkan menurut istilah, khamr adalah segala jenis minuman atau lainnya sehingga menjadi mabuk dan hilang kesadarannya. Adapun sesuatu yang bisa memabukkan dapat berbentuk minuman, serbuk yang dihisap, cairan yang disuntikkan, dapat juga makanan serta tablet, termasuk juga ganja, morfin, nipan, magadon dan sebagainya kesemuanya itu dinamakan khamr atau minuman keras.

Hukum minum-minuman keras atau khamr adalah haram, dan termasuk perbuatan yang tergolong dosa besar. Firman Allah SWT:

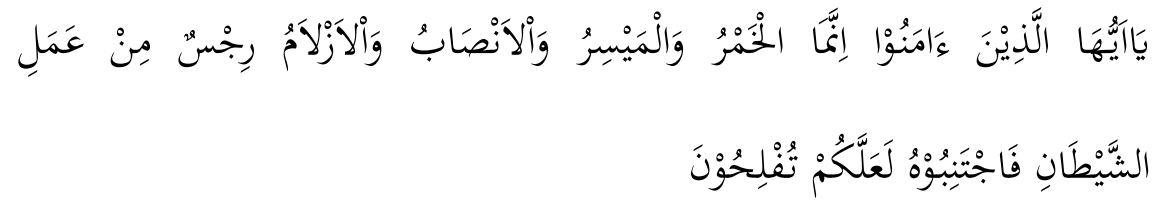

Artinya: "Hai orang-orang yang beriman, sesungguhnya (minuman) arak, berjudi berkorban untuk berhala, mengadu nasib dengan anak panah adalah pebuatan keji termasuk perbuatan syaitan. Maka jauhilah perbuatan-perbuatan itu agar kamu mendapat keberuntungan" (QS. Al Maidah : 90)

Dalam hadits yang lain juga disebutkan sebagaimana Rasulullah SAW bersabda :

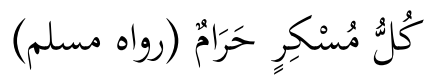

Artinya: "Semua yang memabukkan itu (hukumnya) haram". (HR. Muslim)

Dalam hadits yang diriwayatkan oleh iman Nasa'i dan Abu Daud Rasulullah saw. bersabda :

${ }^{53}$ Wahbah Zuhaily, Fiqih Islam..., h. 48

Al Qalam: Jurnal Ilmiah Keagamaan dan Kemasyarakatan Vol. 13, No. 2, Juli-Desember 2019 
Mibahul Khairani, Susanto: Implementasi Hudud dalam Pandangan Ulama Fiqih; Studi Kritis Tehadap Kitab Fiqih 'Ala Mazahib Al Arba'ah

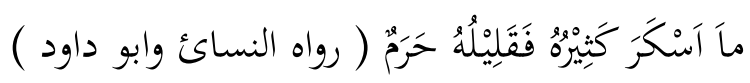

Artinya: "Apapun yang banyak memabukkan, maka sedikitnya pun haram". ( H.R. An-Nasa'i dan Abu Dawud )

Peringatan bagi orang yang meminum-minuman keras akan mendapat dosa besar dan dilaknat oleh Allah swt. :

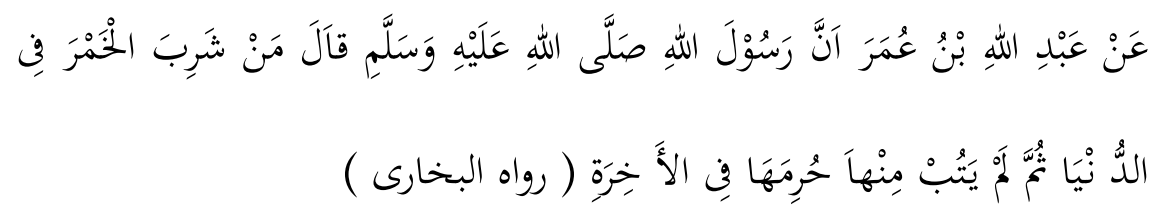

Artinya: "Dari Abdullah bin Umar, Rasulullah saw. bersabda: "Barang siapa minum khomer dan ia tidak bertaubat, maka ia tidak akan memperolehnya di akhirat”. ( H.R. Bukhari )

\section{2) Had Minuman Keras}

Orang yang meminum-minuman keras hukumannya adalah had, dan dianggap sebagai orang fasik, kecuali ia bertaubat. Kefasikan orang yang minum-minuman keras telah disepakati oleh para ulama, baik yang meminum sampai mabuk maupun yang tidak sampai mabuk. Dasar penetapan hukuman bagi peminum minuman keras adalah pertama; pengakuan pelaku bahwa dia benar meminun minuman keras, kedua; kesaksian dua orang laki-laki yang adil dan ada tanda (aroma minuman keras).

Syarat-syarat peminum yang dapat dijatuhi had minuman keras adalah : a) Baligh; b) berakal; c) minum dengan sengaja dan kehendaknya sendiri; d) Islam; e) peminum tahu bahwa yang diminum adalah sesuatu yang memabukkan; f) bukan karena terpaksa meminumnya.

Adapun jumlah pukulan (dera) dalam hukuman minuman keras adalah 40 (empat puluh) kali. Sabda Rasulullah saw : 
Mibahul Khairani, Susanto: Implementasi Hudud dalam Pandangan Ulama Fiqih; Studi Kritis Tehadap Kitab Fiqih 'Ala Mazahib Al Arba'ah

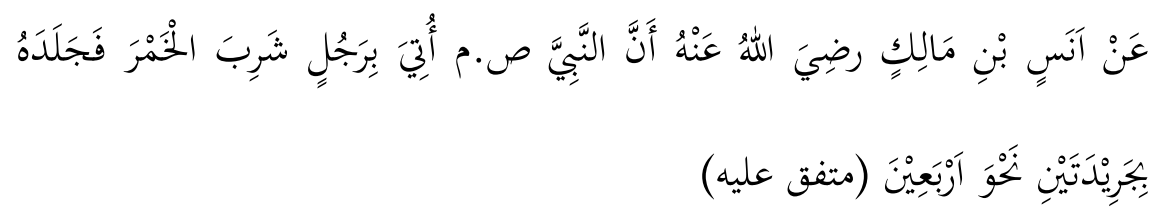

Artinya: "Dari Anas bin Malik ra. Dihadapkan kepada Nabi SAW seseorang yang telah meminum khamr, kemudian beliau menjilidnya dengan dua tangkai pelapah korma kira-kira 40 kali’. (Mutafaq alaih)

Pada riwayat lain Rasulullah saw. Pernah memukul peminum minuman keras yaitu:

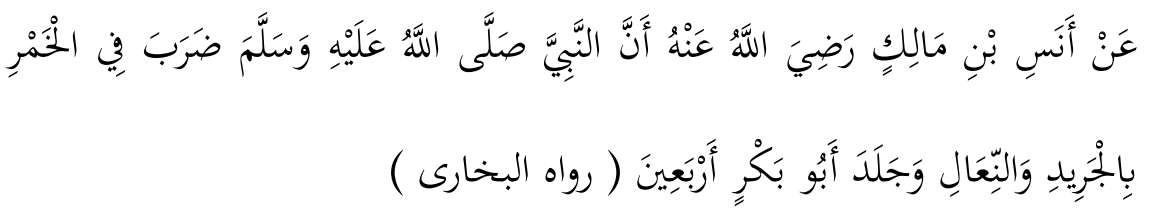

Artinya: "Dari Anas bin Malik radliallahu 'anhu bahwasanya Nabi shallallahu 'alaihi wasallam pernah memukul peminum khamar dengan pelepah kurma dan sandal, dan Abu Bakar pernah mencambuknya sebanyak empat puluh kali’. (HR. Bukhari)

Menurut Imam Syafi'i, Abu Daud dan ulama-ulama Zhahiriyah berpendapat bahwa had bagi peminum minuman keras adalah 40 kali pukulan, akan tetapi hakim dapat menambah 40 kali lagi sehingga jumlahnya 80 kali pukulan. Tambahan pukulan 40 kali tesebut adalah hak hakim sebagai hukuman $t^{\prime} z_{i r}{ }^{54}$

Sedangkan menurut Imam Abu Hanifah, Imam Malik dan Imam Ahmad bin Hambal berpendapat bahwa pukulan dalam had minumminuman keras adalah 80 (delapan puluh) kali. ${ }^{55}$

\footnotetext{
${ }^{54}$ Lihat Nailul Authar..., h. 137. Lihat fiqih Islami.., h. 151

${ }^{55}$ Lihat fiqih Islami.., h. 151
} 
Mibahul Khairani, Susanto: Implementasi Hudud dalam Pandangan Ulama Fiqih; Studi Kritis Tehadap Kitab Fiqih 'Ala Mazahib Al Arba'ah

\section{Syarat dan ketentuan Penerapan hudud}

\section{a. Syarat dilaksanakan hukum had}

Penerapan hudud tidak dilakukan tanpa empat syarat: a) Pelaku kejahatan adalah seorang mukallaf yaitu baligh dan berakal. b) Pelaku kejahatan tidak terpaksa dan dipaksa. c) Pelaku kejahatan mengetahui larangannya. d) Kejahatannya terbukti dan bahwa ia melakukannya tanpa ada syubhat. Hal ini bisa dibuktikan dengan pengakuannya sendiri atau dengan bukti persaksian orang lain.

\section{b. Pelaksana Hudud}

Diwajibkan kepada wali umur (penguasa) untuk menegakkan dan menerapkan Had kepada seluruh rakyatnya berdasarkan dalil dari Al-Qur`an, Sunnah dan Ijma' serta dituntut qiyas yang shahih. Dalil Al-Qur`an di antaranya adalah firman Allah SWT:

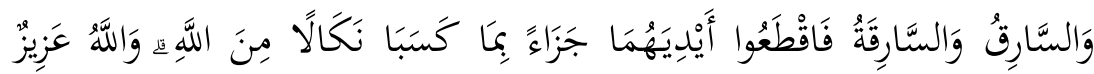

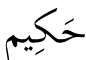

Artinya: "Laki-laki yang mencuri dan perempuan yang mencuri, potonglah tangan keduanya (sebagai) balasan bagi apa yang mereka kerjakan dan sebagai siksaan dari Allah. dan Allah Maha Perkasa lagi Maha Bijaksana. (QS. Al Maidah:38)

Dalil Sunnah di antaranya adalah hadits Ubadah bin Shamit yang mengatakan bahwa Rasulullah bersabda:

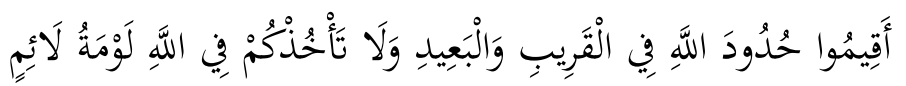

Artinya: "Tegakkanlah hukuman-hukuman (dari) Allah SWT kepada kerabat dan lainnya, dan janganlah kecaman orang yang suka mencela mempengaruhi kamu (dalam menegakkan hukum-hukum) karena Allah SWT.”(HR. Ibn Majah). 
Mibahul Khairani, Susanto: Implementasi Hudud dalam Pandangan Ulama Fiqih; Studi Kritis Tehadap Kitab Fiqih 'Ala Mazahib Al Arba'ah

Demikian juga ulama kaum muslimin sepakat atas hal ini. Tak ada yang berwenang menegakkan hudud, kecuali imam, kepala negara, atau wakilnya (aparat pemerintah yang mendapat tugas darinya). Sebab di masa kerasulan, beliaulah yang melaksanakannya. Demikian pula para khalifahnya sepeninggal beliau. Rasulullah SAW pernah juga mengutus Unais ra. untuk melaksanakan hukum rajam, sebagaimana dalam sabdanya:

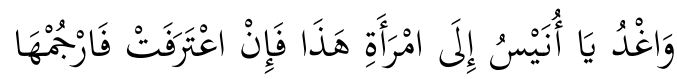

Artinya: "Wahai Unais, berangkatlah menemui isteri orang ini, jika ia mengaku (berzina), maka rajamlah!" (HR al-Bukhari).

Demikian Rasulullah SAW juga memerintahkan para sahabat untuk merajam Ma’iz, dengan menyatakan :

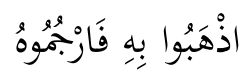

Artinya: "Bawalah ia dan rajamlah!” (HR Bukhari).

Demikian juga karena penentuan hukuman had dibutuhkan ijtihad dan tidak aman dari kezhaliman, maka wajib dilaksanakan oleh imam atau wakilnya.

\section{c. Tidak dibenarkan rekomendasi pembebasan hukuman, bila sudah di meja hijaukan}

Apabila perkaranya telah masuk ke pengadilan atau telah dimeja hijaukan, maka dilarang adanya syafaat (rekomendasi) pembebasan atau pengurangan hukuman. Dalam hal ini, pengadilan tidak boleh menerima syafaat ataupun negosiasi pembatalan putusan. Hal ini dijelaskan Rasulullah dalam hadits 'Aisyah ra. yang berbunyi:

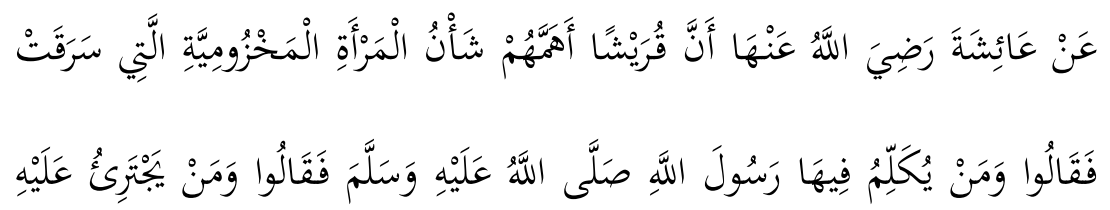


Mibahul Khairani, Susanto: Implementasi Hudud dalam Pandangan Ulama Fiqih; Studi Kritis Tehadap Kitab Fiqih 'Ala Mazahib Al Arba'ah

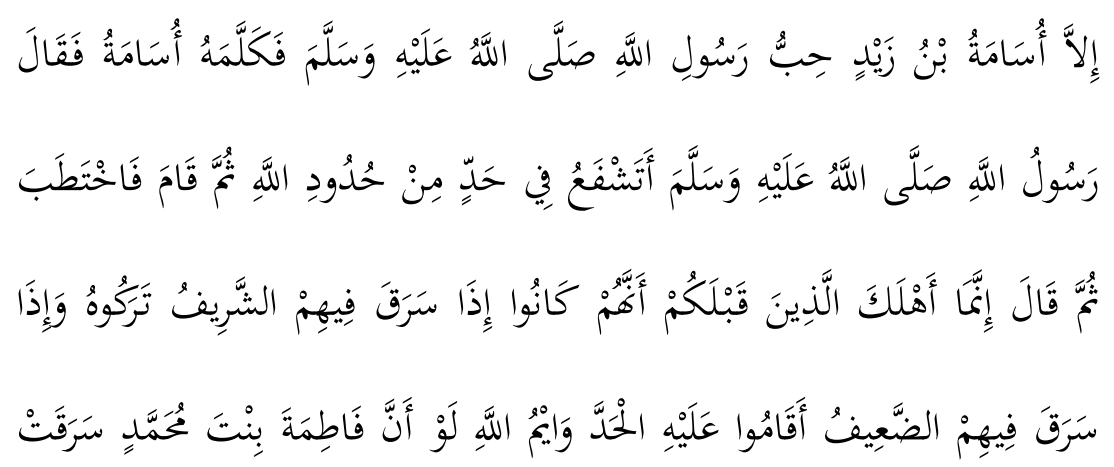

لَقَطَعْتِ يَََهَا

Artinya: "Dari Aisyah ra. yang mengatakan bahwa kaum Quraisy sangat dipusingkan keadaan seorang perempuan suku Makhzum yang melakukan pencurian. Mereka mengatakan, "Siapa yang bisa berbicara dengan Rasulullah SAW (yaitu mengemukakan permintaan supaya perempuan itu dibebaskan)?" Tidak ada yang mau berbicara tentang hal itu, kecuali Usamah kesayangan Rasulullah SAW. Nabi SAW berkata kepada Usamah, "Apakah engkau hendak menolong supaya orang bebas dari hukuman Allah SWT?” Kemudian Rasulullah SAW berdiri lalu berkhutbah, "Hai sekalian manusia, orang-orang sebelum kamu binasa hanyalah disebabkan apabila seorang bangsawan mencuri, mereka biarkan (tidak melaksanakan hukuman kepadanya) dan bila orang miskin mencuri, mereka tegakkan had padanya. Demi Allah, kalaulah seandainya Fatimah binti Muhammad mencuri, niscaya Muhammad memotong tangannya. "56

Dalam hadits yang mulia ini Rasulullah mengingkari orang yang memberi syafaat atau membatalkan sanksi dalam hukuman had

${ }^{56}$ Ahmad bin Ali Ibn Hajar al Asqalani, Fathu al Bari, jil.12 (Beirut: Dar Al Kutub,tt) h. 87 dan lihat Shahih Muslim jilid.2 h.1315 no 1688.

Al Qalam: Jurnal Ilmiah Keagamaan dan Kemasyarakatan Vol. 13, No. 2, Juli-Desember 2019 
Mibahul Khairani, Susanto: Implementasi Hudud dalam Pandangan Ulama Fiqih; Studi Kritis Tehadap Kitab Fiqih 'Ala Mazahib Al Arba'ah

setelah sampai ke pengadilan dan sudah dilakukan gelar perkara. Adapun bila belum sampai ranah pengadilan maka diperbolehkan dilakukan negosiasi.

Ibnu Taimiyah berpendapat tidak boleh menggagalkan (hukuman had) dengan syafaat, hadiah dan yang lainnya. Siapa yang menggagalkannya karena hal ini padahal ia mampu menerapkannya, maka semoga laknat Allah SWT, malaikat dan semua manusia menimpanya. ${ }^{57}$

\section{E. Kesimpulan}

Dari pembahasan di atas dapat ditarik kesimpulan, bahwasanya hudud adalah sanksi yang telah ditetapkan kadarnya oleh Allah SWT, tidak ada hak bagi hakim untuk menambah atau mengurangi sanksi tersebut. Ada beberapa Jarimah yang mendapakan hukuman dengan Had, yaitu 1) Had zina (hukuman zina) 2) Had al-Qadzf 3) Had al-Khamr 4) Had as-Sariqah) 5) Had al-Hirabah (hukuman para perampok) 6) Had al-Baghi (hukuman pembangkang) 7) Had ar-Riddah.

Had zina bisa ditetapakan dengan dua cara, yaitu Syahadah (saksi), dan Iqrar (pengakuan). Penetepan zina dengan syahadah tidak bisa langsung dijatuhkan vonis sebelum tercukupi saksinya sebantak empat orang laki-laki, dan semuanya mampu menjelaskan kronologi terjadinya perzinahan dengan detail, jika salah satunya tidak mampu menjelaskan dengan detail maka para saksi dikenakan sanksi had qazaf. Sedangakan pengakuan mujrim tentang perbuatannya kalau dia ucapkan sekurang-kurangnya empat kali.

Liwath (homoseksual) disamakan dengan zina, dirajam jika pelakunya sudah menikah atau pernah menikah dan di jild jika pelakunya belum menikah. Sedangkan sihaq (lesbian) pekakunya dikenakan sanksi ta'zir, di analogikan dengan perbuatan mesum antara seorang laki-laki dan perempuan yang tidak sampai kepada zina farji.

${ }^{57}$ Ibn Taymiyah, Majmu’ Al-Fatawa, Jilid 28 (Beirut: Dar Kutub, tt) h. 298. 
Mibahul Khairani, Susanto: Implementasi Hudud dalam Pandangan Ulama Fiqih; Studi Kritis Tehadap Kitab Fiqih 'Ala Mazahib Al Arba'ah

Isti'jarul Al Mar'ah li Azzina (PSK), laki-laki yang menyewa perempuan untuk melakukan perbuatan zina dikenai had zina, hampir tidak ditemukan perbedaan pendapat tentang hal ini. Perbuatan zina yang dilakukan se mahram, ulama sepakat sanksi adalah dibunuh. Perbutan istimna', pelaku dari perbuatan ini dikenakan sanksi ta'zir, sedangkan ityaan al bahimah pelakunya juga dihukun dengan ta'zir dan hewannya di sembelih.

Sedangkan khamar adalah segala jenis benda yang memabukkan jika di konsumsi. Peminum khamar akan dikenai sanksi, yang dibuktikan dengan dua orang saksi dan atau dengan pengakuan dari peminum. Adapun pelakasanaan hudud, dilaksankan oleh pemerintah bukan dilaksanakan oleh perorangan. Penetakan hudud melalui putusan hakim. Jika perkara sudah dimeja hijaukan maka tidak boleh ada rekomendasi pembebasan. 
Mibahul Khairani, Susanto: Implementasi Hudud dalam Pandangan Ulama Fiqih; Studi

Kritis Tehadap Kitab Fiqih 'Ala Mazahib Al Arba'ah

\section{Daftar Pustaka}

Abdurrahman Al Jazairy, Kitab al Fiqhi 'Ala Madzahib al Arba'ah, Beirut: Dar Al Fikri Al Ilmiyah, 1990.

Al Qur'an Al Karim

Abu Abdullah Muhammad bin Ismail Al Bukhari, Shahin Al Bukhari, Jilid VI, Kairo: Maktabah Nazar Musthafa al Baz, 2004

Abu Zakaria Mahyuddin Yahya bin Syaraf, Ali bin Abdul Kafi As Subki, Al Majmu Syarh Al Muhadzab, Jilid 22 Kairo: Mathba'ah Al Ashimah, tt

Ahmad bin Ali Ibn Hajar al Asqalani, Fathu al Bari, Beirut: Dar Al Kutub,t

Ibn Taymiyah, Majmu’ Al-Fatawa, Beirut: Dar Kutub, tt

Lexy J. Meleong, Metododlogi Penelitian Kualitatif Bandung: PT. Remaja RosdaKarya, 2003.

Lihat http//www. Jaafaridris.com, diakses 13 Nopember 2017.

Majma' Lughah Arabiyah, Al Mu’jam Al Wajiz, Kairo: Wijzarah At Tarbiyah Wa At Ta'lim, 2006.

Muhammad Zuhaili, Al Mu'tamad Fi Fiqhi As Syafi’i, Juz. V, Damaskus: Dar Al Qalam, 2011.

Imam Nawawi, Syarah Shahih Muslim, Kairo: Maktabah Taufiqiyah, 2011.

Muhammad bin Isa At Tirmizi, Jami at Tirmizi, Mansurah mesir: Dar Al Kalimah, 2011.

Sugiono, Metode Penelitian Kuantitatif, Kualitatif dan R\&D, Bandung: Alfabet, 2013.

Sulaiman Rasjid, Fiqih Islam, (Bandung: Sinar Baru Algesindo offset, 2013

Wahbah Zuhaily, Fiqih Islam Wa Adillatuhu, Jilid. VI, Damaskus:Dar Al Fikri, $\mathrm{tt}$

Imam Syaukani, Nailul Authar

Al Qalam: Jurnal Ilmiah Keagamaan dan Kemasyarakatan

Vol. 13, No. 2, Juli-Desember 2019 